\title{
Erratum to: Bacterial lipoxygenases, a new subfamily of enzymes? A phylogenetic approach
}

\author{
Jhoanne Hansen • Albert Garreta • Maria Benincasa • \\ M. Carmen Fusté • Montserrat Busquets • \\ Angeles Manresa
}

Published online: 17 July 2013

(C) Springer-Verlag Berlin Heidelberg 2013

Erratum to: Appl Microbiol Biotechnol (2013) 97:5175-5176

DOI 10.1007/s00253-013-4887-9

Erratum of Acknowledgements section:

"The financial support of the Comissió Interdepartamental de Recerca I Tecnologia CIRIT project 2005GR00143 and the Comisión Interministerial de Ciencia y Tecnologia (CICYT), project CTQ2007-60749/PPQ and project HBP2006-0027 of the Ministerio de Educación y Ciencia is gratefully acknowledged. J Hansen, postgraduate student of the Programa de Pós-Graduação em Microbiologia Agropecuária - Unesp, Jaboticabal, São Paulo, Brazil, thank CAPES - Coordenação de Aperfeiçoamento de Pessoal de Nível Superior for the partial financing studies."

The online version of the original article can be found at http://dx.doi.org/ 10.1007/s00253-013-4887-9.

J. Hansen · A. Garreta $\cdot$ M. C. Fusté · A. Manresa $(\bowtie)$

Laboratori de Microbiologia, Facultat de Farmàcia,

Universitat de Barcelona, Barcelona 08028, Spain

e-mail: amanresa@ub.edu

M. Busquets

Departament de Bioquimica i Biologia Molecular,

Facultat de Biologia, Universitat de Barcelona,

Barcelona 08028, Spain

M. Benincasa

FATEC - Faculdade de Tecnologia de Jaboticabal, Laboratórios e Secretaria Administrativa, 14883-130,

Jaboticabal, SP, Brazil 